\title{
Model Electrochemical Biosensor for the Detection of Methanol in Aqueous Solutions with Yeast Cells
}

\author{
Zala Štukovnik, ${ }^{1}$ Urban Bren ${ }^{1,2}$ and Martin Rozman ${ }^{1, *}$ \\ ${ }^{1}$ University of Maribor, Faculty of Chemistry and Chemical Engineering, Smetanova ulica 17, 2000 Maribor, Slovenia \\ ${ }^{2}$ University of Primorska, Faculty of mathematics, Natural sciences and information technologies, Glagoljaška Ulica 8, \\ 6000 Koper, Slovenia \\ *Corresponding author: E-mail: martin0rozman@gmail.com
}

Received: 11-27-2020

\begin{abstract}
An electrochemical device that serves as a model biosensor and contains yeast Saccharomyces cerevisiae as the active biological element was developed. Different configurations of the electrochemical cells were assembled and tested. Stainless steel was used in the electrochemical cell composition process and the surface of this metal electrode was modified with a thin layer of $\mathrm{WO}_{3}$ if necessary. The yeast Saccharomyces cerevisiae was adhered to the working electrode. The resulting model biosensor was then used to monitor the response to a $10 \% \mathrm{CH}_{3} \mathrm{OH}$. For detection of biological activity, the electrochemical impedance spectroscopy (EIS) method was applied with a portable potentiostat/galvanostat, where the Bode and the Nyquist plots were interpreted. The stability of the device was beforehand determined by measuring the open circuit potential (OCP). The topography of the electrodes was inspected using the techniques of scanning electron microscopy and optical microscopy. The investigated model biosensor serves as a case study for the development of more complex biosensors that utilize living cells as the active layer.
\end{abstract}

Keywords: Biosensor, electrochemistry, electrochemical impedance spectroscopy, yeast Saccharomyces cerevisiae

\section{Introduction}

A biosensor represents an analytical device that combines a biological element and a physical transmitter to generate a measurable signal proportional to the concentration of the analyte. ${ }^{1,2,3}$ The quality of the information provided by the biosensor depends on the type of analyte solution, the active biological component, the design of the biosensor and the properties of the physical transducer. ${ }^{3}$ Biosensors can be classified according to the method of physico-chemical conversion or according to the type of biologically active element. Based on the transducer, biosensors are classified into electrochemical, optical and mechanical biosensors. ${ }^{4}$ Active biological components can generally include unicellular organisms, enzymes, antibodies, cells, organelles or tissues. ${ }^{5}$

The aim of this study was to develop an electrochemical cell that is transferable and connectable to smartphones, computers, servers, etc., while remaining highly specific, responsive and repeatable.

The presented electrochemical cell is a part of a biosensor and it is designed as a three-electrode electrochemical system. At the working electrode (WE) the process is monitored, the reference electrode (RE) has a constant potential that does not change during the process while the counter electrode $(\mathrm{CE})$ provides the current required to detect the electrochemical cell response. ${ }^{6,7}$

In an electrochemical cell intended for use in biosensorics, a biological component capable of recognizing and quantifying specific stimuli or pulses is applied to the working electrode. ${ }^{8}$ Electrodes for biosensors can be reused from other electrochemical systems and can incorporate different materials, with focus on non-toxic metals and metal oxides. ${ }^{9,10}$ As a biological component, the Saccharomyces cerevisiae yeast was used, which has many advantageous properties that make it useful for biosensing: the robustness of the cells, the ease of maintenance, and the rate of the cell production. ${ }^{11,12}$ Yeast Saccharomyces cerevisiae represents a single-celled eukaryotic organism used primarily in the food industry in the preparation of bakery products and alcoholic beverages. ${ }^{13}$ Yeast Saccharomyces cerevisiae are chemoorganotrophic and anaerobic organisms classified in the kingdom of fungi, the phylum Ascomycota, the class Saccharomycetes, the order Saccharomycetales and the family Saccharomycetaceae. ${ }^{14}$ Saccharomyces cerevisiae can exist in two different forms, the hap- 
loid or the diploid form. ${ }^{15} \mathrm{~A}$ yeast cell possesses typical properties of a single-nucleus eukaryotic cell and characteristic organelles such as vacuoles and lipid droplets. ${ }^{16}$ Yeast cells are usually spherical to slightly spherical and occasionally ellipsoidal to cylindrical in shape. ${ }^{17}$ Yeasts, unlike certain other biological components, do not require sophisticated sterile techniques or complex media and are also economically advantageous. ${ }^{12}$

The electrochemical impedance spectroscopy (EIS) method was used for detection. With the EIS technique the frequency response of the electric current was measured and thus provided data on the yeast adhesive layer on the electrode surfaces. EIS represents a non-destructive method with which one can quantify certain parameters and simultaneously trace several electrochemical processes. ${ }^{18}$ The measurement comprises the real (electric resistance) and the imaginary (capacitance) component of the impedance response of an electrochemical system. ${ }^{19}$ Electrochemical impedance spectroscopy has been widely used in the production and optimization of biosensors, ${ }^{20,21}$ as this method allows characterization of the biological component attached to the sensor and the analyte present in the sample. Because biosensors generate a rapid response, they can be used to monitor molecular events in real time. ${ }^{22}$

To determine cell mortality, the method of staining cells with methylene blue was applied. When cells are stained with methylene blue, dead cells remain blue while living cells reduce methylene blue and become colorless due to the reaction..$^{23}$ In the current study a model biosensor containing yeast Saccharomyces cerevisiae as the active biological element was developed and tested using electrochemical impedance spectroscopy as well as scanning electron microscopy and optical microscopy.

\section{Experimental}

Various procedures for composition of electrochemical cells have been tested. In the process of assembling the electrochemical cell, stainless steel type SS316 (manufacturer TBJ Industries, Germany) was used and in some experiments, the surface of the metal electrode was modified with a thin layer of $\mathrm{WO}_{3}$. Yeasts Saccharomyces cerevisiae were applied to the working electrode as a biological component. Using a model biosensor, the yeasts response to a $10 \% \mathrm{CH}_{3} \mathrm{OH}$ solution when changing various parameters was monitored.

Model electrochemical devices that used different working electrodes and utilized different dimensions were assembled and tested. The electrodes were manufactured in two different dimensions (figure 1): dimension of electrode $20 \mathrm{~mm} \times 2 \mathrm{~mm}$ where the active component was applied to $5 \mathrm{~mm} \times 2 \mathrm{~mm}$ (figure 1a) and dimension of electrode 20 $\mathrm{mm} \times 5 \mathrm{~mm}$ where the active component was applied to 5 $\mathrm{mm} \times 5 \mathrm{~mm}$ (figure $1 \mathrm{~b}$ ). The position of electrodes was al- ways side-by-side and from left to right placing the reference (RE), the counter (CE) and finally the working electrode (WE) which we marked the RCW configuration. $0.050 \mathrm{~mm}$ thick stainless steel and stainless steel covered with a thin layer of $\mathrm{WO}_{3}$ was used. The electrochemical cell consisted of three electrodes, where the biological component or yeast Saccharomyces cerevisiae was applied to the working electrode (WE). Electrodes were insulated on fixation side. The system was closed with glass.

Biosensor device manufacturing process:

- Production of electrodes with dimension $20 \mathrm{~mm} \times 2$ $\mathrm{mm}$ for small electrochemical cell and dimension 20 $\mathrm{mm} \times 5 \mathrm{~mm}$ for large electrochemical cell. Electrodes were cut from a $0.050 \mathrm{~mm}$ thick stainless steel foil and from a $0.050 \mathrm{~mm}$ thick stainless steel foil covered with a thin layer of $\mathrm{WO}_{3}$.

- Application of a biological component on the working electrode (WE) by spin coater at the coating speed of $2000 \mathrm{rpm}$ for $10 \mathrm{~s}$.

- Placement and fixation of electrodes on the glass support in the RCW configuration described previously.

- System closure with small glass slide. a)

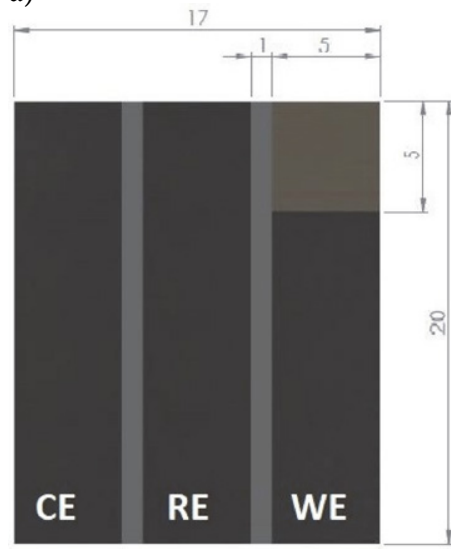

b)

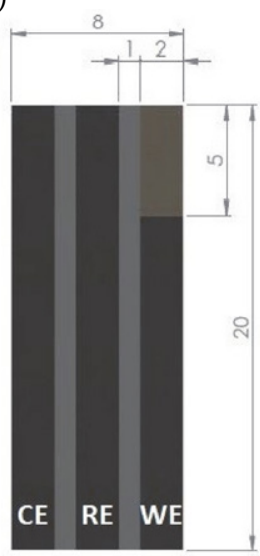

\section{- ACTIVE BIOLOGICAL COMPONENT}

- electrode

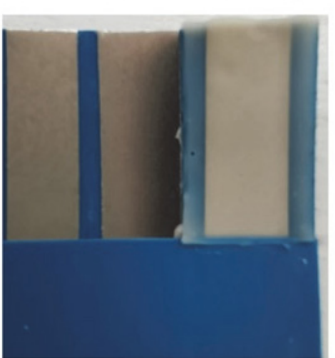

Figure 1: In figure 1a, large electrochemical cell with three electrodes in reference-counter-working (RCW) side-by-side configuration is presented. Dimension of electrode is $20 \mathrm{~mm} \times 5 \mathrm{~mm}$, where the active biological component is applied to $5 \mathrm{~mm} \times 5 \mathrm{~mm}$. In figure $1 \mathrm{~b}$ a small electrochemical cell with three electrodes in RCW side-by-side configuration is depicted. Dimension of electrode is $20 \mathrm{~mm} \times 2 \mathrm{~mm}$, where the active biological component is applied to $5 \mathrm{~mm} \times 2 \mathrm{~mm}$. An actual assembled device, with biological component is presented on lower right part of the figure, with active surface area of each individual electrode being $5 \mathrm{~mm} \times 2 \mathrm{~mm}$. 
Two solutions were prepared for the measurements: $0.9 \% \mathrm{NaCl}$ solution (saline) and $10 \% \mathrm{CH}_{3} \mathrm{OH}$ in $0.9 \% \mathrm{Na}-$ $\mathrm{Cl}$ solution. The solution was injected into the system. For evaluation of electrochemical cells electrochemical impedance spectroscopy method (EIS) was used.

The measurements were carried out with a PalmSens 4 potentiostat/galvanostat. The frequency range for EIS tests was $10 \mathrm{mHz}$ to $100 \mathrm{kHz}$, the recording range of the electrical current measurement range was between $1 \mathrm{nA}$ and $10 \mathrm{~mA}$, the amplitude potential was $20 \mathrm{mV}$, and the number of measured frequency points was $61=10 / \mathrm{dec}$.

Electrochemical impedance spectroscopy was used to obtain the data on the events on the surface of the electrode and the applied layers, and the Bode and Nyquist plots were interpreted as a result.

The stability of the device and the prepared layers was previously determined by measuring the potential of the open circuit (OCP), in which the potential difference between the reference electrode (RE) and the working electrode (WE) is measured.

Biosensor device connection and testing procedure:

- Connection of the biosensor device to the potentiostat/galvanostat.

- Addition of $0.9 \% \mathrm{NaCl}$ solution. The solution was applied with syringe onto top of the open device, after which the device was sealed with clamps to prevent movement of individual components. After addition of solution, the device was for approximately 5 min to ensure that all of the electrodes were sufficiently soaked.

- Open Circuit Potential measurement (OCP). The time of the measurement was $30 \mathrm{~s}$.

- Measurement of electrochemical impedance spectroscopy (EIS). The expected duration of the measurement was $2 \mathrm{~min}$ and $12 \mathrm{~s}$, and the time was commonly prolonged up to $3 \mathrm{~min}$.

- Addition of $0.9 \% \mathrm{NaCl}$ solution with $10 \% \mathrm{CH}_{3} \mathrm{OH}$. The measurements were carried out after exposure to methanol as a toxic component. A paper tissue was placed under electrochemical cell and a $1 \mathrm{~mL}$ syringe fitted with needle that was filled with investigating solution was carefully stuck onto side of device in such way, that it did not touch biological component. After positioning of the needle, the content of the syringe was dumped into the electrochemical cell, ensuring that the device was excessively soaked with new solution. This rinsing process was repeated at least three times. Electrochemical cells were rinsed with $0.9 \% \mathrm{NaCl}$ core solution with added $\mathrm{CH}_{3} \mathrm{OH}$ to prevent loss of electrolyte and change of conductive properties.

- Excess liquid was removed with paper tissue and device was then left connected to potentiostat/galvanostat in idle mode for $60-90 \mathrm{~s}$ for the methanol to have effect on the cells before open circuit potential (OCP) measurement was carried out.
- Open circuit potential measurement (OCP). The time of the measurement was $30 \mathrm{~s}$.

- Measurement of electrochemical impedance spectroscopy (EIS). The expected duration of the measurement was $2 \mathrm{~min}$ and $12 \mathrm{~s}$, where the time was commonly prolonged to up to $3 \mathrm{~min}$ to enable assembled cell to achieve stable open circuit potential equilibrium, with potential drift being less than $0.2 \mathrm{mV} / \mathrm{s}$. The morphology of the electrodes was additionally verified by the technique of scanning electron microscopy (SEM) and by classical microscopy, where the number of living yeast cells of the species Saccharomyces cerevisiae on the surface of the electrodes was examined. To determine cell mortality, the method of staining cells with methylene blue was used. When cells are stained with methylene blue, dead cells remain blue stained and living cells reduce methylene blue and become colorless due to the reaction. ${ }^{23}$ For methylene blue dye testing, $50 \mathrm{~mL}$ of both original $0.9 \% \mathrm{NaCl}$ blank solution and $50 \mathrm{~mL}$ of $0.9 \% \mathrm{NaCl}$ and 10 $\% \mathrm{CH}_{3} \mathrm{OH}$ solution were modified by adding $0.5 \mathrm{~mL}$ of methylene blue dye solution that was prepared from $0.1 \mathrm{~g}$ of powdered methylene blue in $50 \mathrm{~mL}$ of demineralized water. Cells were first exposed to the dyed saline and afterwards to the dyed $10 \% \mathrm{CH}_{3} \mathrm{OH}$ solution. The duration of exposure to dyed saline and in dyed methanol was approximately 60-90 s, similar to the undyed devices that were used in electrochemical measurements (OCP, EIS). For technique of scanning electron microscopy (SEM), Zeiss ULTRA plus field emission microscope (accelerating voltage 0.02 to $30 \mathrm{kV}$ and $100,000 \mathrm{x}$ magnification) was used. The configuration of the microscope enables quality analysis of practically all solid nonvolatile samples. For optical microscopy Olympus SZX16 microscope and 120x magnification was used.

\section{Results and Discussion}

Model electrochemical cells of different dimensions described previously in experimental section were assembled and tested.

\section{1. Electrochemical Impedance Spectroscopy (EIS)}

\section{a) Biosensor with stainless steel working electrode}

The impedance response of the biosensor with yeast cells attached to stainless steel in the absence and presence of $\mathrm{CH}_{3} \mathrm{OH}$ as a toxic component was measured.

In the graphs, EIS Nyquist plots (Figures $2 \mathrm{a}$ and $2 \mathrm{~b}$ ), representing the response in complex units are represented. A $0.9 \%$ sodium chloride $(\mathrm{NaCl})$ solution was first added to the system followed by a solution consisting of $0.9 \%$ sodium chloride $(\mathrm{NaCl})$ and $10 \%$ methanol $\left(\mathrm{CH}_{3} \mathrm{OH}\right)$. With the addition of $\mathrm{NaCl}$ solution to the system, the charge transfer and then the diffusion process are shown 
on the plots. The capacitance (imaginary part of impedance) and the resistance (real part of impedance) increased with the frequency drop.

In the Nyquist diagram of the large electrochemical cell (Figure $2 \mathrm{a}$ ), the solution resistance $\left(\mathrm{R}_{\mathrm{S}}\right)$, the capacitance of the electric double layer $\left(\mathrm{C}_{\mathrm{dl}}\right)$, and the charge transfer resistance $\left(\mathrm{R}_{\mathrm{ct}}\right)$ are detected in kinetic controlled process of the EIS spectrum and are displayed as semi-circle pattern. Mass transfer-controlled process of the EIS spectrum describes the diffusion as a linear behavior.

In the Nyquist diagram of the small electrochemical cell (Figure $2 \mathrm{~b}$ ), the solution resistance $\left(\mathrm{R}_{\mathrm{S}}\right)$, the capacitance of the electric double layer $\left(\mathrm{C}_{\mathrm{dl}}\right)$, the charge transfer resistance $\left(R_{c t}\right)$ and the Warburg impedance $\left(Z_{w}\right)$, which describes the process of transferring ions through layers and is presented in the Nyquist diagram as a linear behavior with a gradient of $45^{\circ}$ are detected. The semi-circle is smaller, confirming a higher conductivity and a smaller charge transfer resistance $\left(\mathrm{R}_{\mathrm{ct}}\right)$.

The Bode plots presented in the supplementary information (Figures $1 \mathrm{~S}$ and $2 \mathrm{~S}$ ) consist of two spectra simultaneously (impedance spectrum and phase spectrum), where the dependence of impedance $(Z)$ and phase angle on frequency is shown. In the impedance spectrum, the activity on the working electrode is determined according to the slopes of the line, and on the phase spectrum the activity is determined according to a phase angle. In the Bode plot, as in the Nyquist plot, it appears that the resistance and capacitance decreased with the addition of $10 \%$ $\mathrm{CH}_{3} \mathrm{OH}$ solution.

In the Bode diagram of large electrochemical cell (Figure 1S), with the addition of $\mathrm{NaCl}$ solution, the solution resistance $\left(R_{s}\right)$ with gradient of 0 in impedance spectrum, then the capacitance of the electric double layer $\left(\mathrm{C}_{\mathrm{dl}}\right)$ with gradient of -1 , which occurs at the phase boundary between the electrode and the electrolyte, the charge transfer resistance with gradient of $0\left(\mathrm{R}_{\mathrm{ct}}\right)$, which occurs due to the electrochemical reaction or charge transfer between the electrolyte and the metal, and the diffusion with gradient of -0.5 (Warburg impedance) were detected. With the addition of $10 \% \mathrm{CH}_{3} \mathrm{OH}$ solution, a similar solution resistance $\left(\mathrm{R}_{\mathrm{s}}\right)$, lower capacitance of the electric double layer $\left(\mathrm{C}_{\mathrm{dl}}\right)$ and more pronounced diffusion were observed. Negative phases are lower than usual, it can be concluded that the charge transfer resistance $\left(\mathrm{R}_{\mathrm{ct}}\right)$ is high.

The Bode plot of the small electrochemical cell is represented in the supplementary information as Figure $2 \mathrm{~S}$. With the impedance spectrum curve in the direction of frequency decay, „non-ideal“ capacitor (CPU) which describes the capacitance of the electric double layer $\left(\mathrm{C}_{\mathrm{dl}}\right)$ and has a gradient of about -1 is represented. In the phase spectrum, negative phase angle of $80^{\circ}$ corresponds to a capacitance of the electric double layer. At lower frequencies, diffusion $\left(Z_{w}\right)$ is observed, which is shown in the impedance spectrum with a gradient of -0.5 and in the phase spectrum with a negative phase angle of $45^{\circ}$.
Nyquist plots and Bode plots show that the addition of $10 \% \mathrm{CH}_{3} \mathrm{OH}$ solution decreased the resistance and capacitance in comparison to addition of $\mathrm{NaCl}$ solution to the system, indicating that the electrode surface was released and, consequently, that $\mathrm{CH}_{3} \mathrm{OH}$ caused the death of Saccharomyces cerevisiae cells.

a)

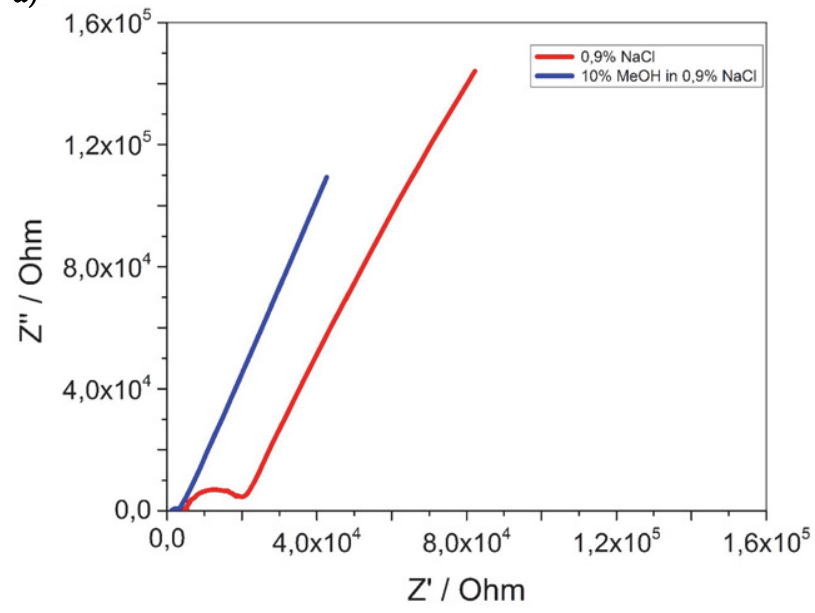

b)

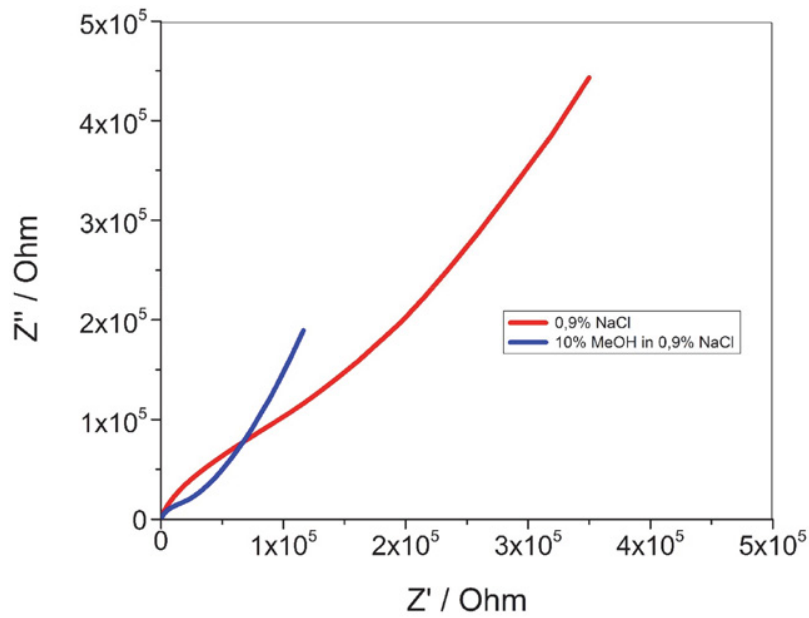

Figure 2: Nyquist diagrams of the EIS measurement on a larger biosensor (Figure 2a) and on a smaller biosensor (Figure $2 \mathrm{~b}$ ) using a working electrode of stainless steel are depicted, where the red curve shows the measurement of a $0.9 \% \mathrm{NaCl}$ solution added to the system and the blue curve shows the measurement of a $0.9 \% \mathrm{NaCl}$ solution with $10 \% \mathrm{CH}_{3} \mathrm{OH}$ added to the system.

\section{b) Biosensor with stainless steel coated with thin layer of trioxotungsten working electrode}

As with the stainless steel working electrode biosensor, the EIS measurements were repeated for the $\mathrm{WO}_{3}$-coated stainless steel working electrode biosensor of various sizes. $0.9 \%$ sodium chloride $(\mathrm{NaCl})$ solution was injected to the system first, followed by $10 \%$ methanol $\left(\mathrm{CH}_{3} \mathrm{OH}\right)$ solution. The capacitance (imaginary part of impedance) and the resistance (real part of impedance) increased with frequency drop. 
The diagram shows resistance response due to process of the charge transfer in the electrolyte and then the additional resistance response due to the diffusion layer. With the addition of $10 \% \mathrm{CH}_{3} \mathrm{OH}$ solution, the resistance and the capacitance response are both decreased, suggesting a change on the electrode surface.

In the case of the biosensor with a larger working electrode dimension $(20 \mathrm{~mm} \times 5 \mathrm{~mm})$ represented in Figure 3a, the Nyquist plot shows a decrease in the resistance and the capacitance with the addition of $\mathrm{CH}_{3} \mathrm{OH}$ compared to the measurement where $\mathrm{NaCl}$ solution was added. Kinetic controlled process describes the solution resistance $\left(R_{s}\right)$, and the charge transfer resistance $\left(R_{c t}\right)$, where the charge transfer resistance $\left(\mathrm{R}_{\mathrm{ct}}\right)$ is more profound in comparison to electrochemical cells without $\mathrm{WO}_{3}$ coat. Mass transfer-controlled process of the EIS spectrum describes diffusion $\left(Z_{\mathrm{w}}\right)$ as linear behavior. In the case of the biosensor with a smaller working electrode dimension

a).

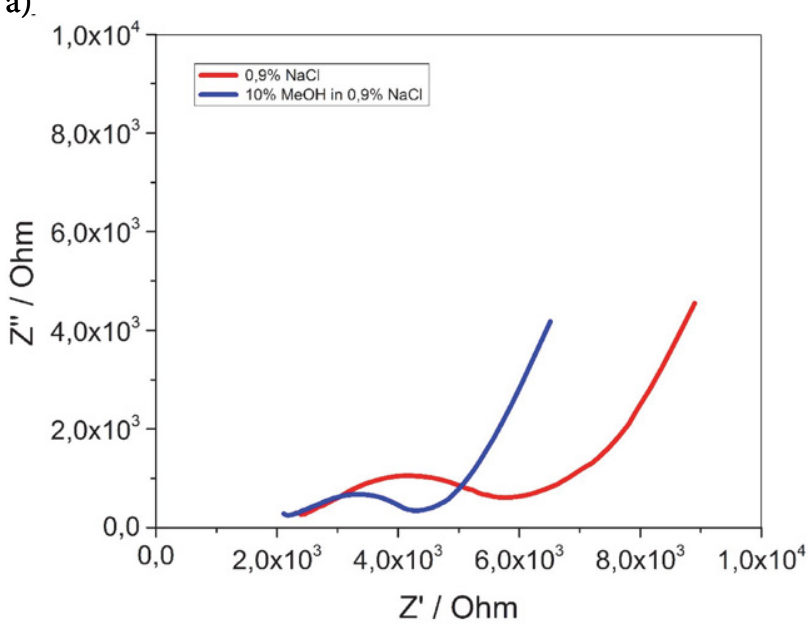

b)

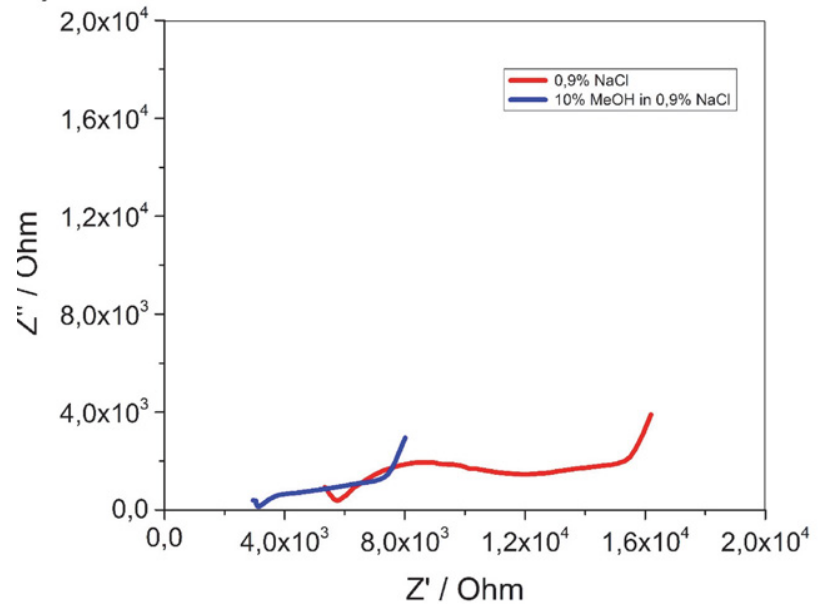

Figure 3: Nyquist diagram of the EIS measurement of a larger (Figure $3 \mathrm{a}$ ) and smaller (Figure $3 \mathrm{~b}$ ) biosensor using a working electrode of stainless steel coated with a thin layer of $\mathrm{WO}_{3}$, where the red curve represents the measurement of $0.9 \% \mathrm{NaCl}$ solution added to the system and the blue curve represent the measurement of $0.9 \%$ $\mathrm{NaCl}$ solution with $10 \% \mathrm{CH}_{3} \mathrm{OH}$ added to the system.
$(5 \mathrm{~mm} \times 2 \mathrm{~mm}$ ), the Nyquist diagram (Figure $3 \mathrm{~b}$ ) shows a decrease in resistance with the addition of $\mathrm{CH}_{3} \mathrm{OH}$ enriched solution compared to the measurement where only $\mathrm{NaCl}$ solution was added. The capacitance (imaginary part of the impedance) did not change significantly in the Nyquist plot, but the change is visible in the Bode diagram, where it is slightly lower with the addition of $\mathrm{CH}_{3} \mathrm{OH}$ solution than with the addition of $\mathrm{NaCl}$ solution.

In the Bode plot of the biosensor with larger electrodes dimension ( $20 \mathrm{~mm} \times 5 \mathrm{~mm}$ ), as in the Nyquist diagram, it is seen that the resistance and capacitance decreased with the addition of $10 \% \mathrm{CH}_{3} \mathrm{OH}$ solution. In the Bode diagram (Figure 3S) with the addition of $\mathrm{NaCl}$ solution and then the addition of $\mathrm{CH}_{3} \mathrm{OH}$ solution, at higher frequencies the solution resistance $\left(\mathrm{R}_{s}\right)$, the charge transfer resistance $\left(R_{c t}\right)$ and the capacitance of the electric double layer $\left(\mathrm{C}_{\mathrm{dl}}\right)$ formed at the phase boundary between the electrode are represented. At lower frequencies Warburg impedance $\left(Z_{\mathrm{w}}\right)$ is shown.

In the Bode diagram of the biosensor with smaller electrodes dimension $(20 \mathrm{~mm} \times 2 \mathrm{~mm})$ (Figure $4 \mathrm{~S})$, the solution resistance, then the capacitance of the electric double layer $\left(\mathrm{C}_{\mathrm{dl}}\right)$ and the charge transfer resistance $\left(\mathrm{R}_{\mathrm{ct}}\right)$, and diffusion as Warburg impedance $\left(\mathrm{Z}_{\mathrm{w}}\right)$ are observed at higher frequencies with the addition of $\mathrm{NaCl}$ solution and with addition of $\mathrm{CH}_{3} \mathrm{OH}$ solution. The charge transfer resistance is more pronounced in regular $\mathrm{NaCl}$ solution compared to the addition of $\mathrm{CH}_{3} \mathrm{OH}$ enriched solution, again most likely due to the cells fully blocking the electrode surface when no methanol is present. Additionally, resistance in general due to electron transfer is higher compared to electrodes that are not coated with the $\mathrm{WO}_{3}$ layer.

The electric equivalent circuit and the fitted impedance spectrum of the large electrochemical cell with the stainless steel working electrode is presented in the supplementary information as Figure 5S and Figure 6S, and the electric equivalent circuit and the fitted impedance spectrum of the large electrochemical cell with the stainless steel covered with $\mathrm{WO}_{3}$ working electrode is presented in the supplementary information as Figure $7 \mathrm{~S}$ and Figure $8 \mathrm{~S}$.

The limit of detection (LOD) for each electrochemical cell was estimated by performing measurements at the six different concentrations of the $\mathrm{CH}_{3} \mathrm{OH}: 0.0 \%, 0.1 \%$, $0.5 \%, 1.0 \%, 5.0 \%$ and $10.0 \%$ of percent by volume and then comparing obtained data. The blank solution consisted of $0,9 \% \mathrm{NaCl}$ solution (saline). The minimum reference total impedance $(\mathrm{Z})$ value for LOD was established at approximately $\Delta=3 \mathrm{k} \Omega$ for 2 measurements at selected concentration and at lowest frequency $\left(10^{0.9} \mathrm{~Hz}\right)$. This is a value that can be determined with sufficient repeatability and represent $30 \%$ error at lower impedance $\left(10^{4} \Omega\right)$ and $3 \%$ error at higher impedance $\left(10^{5} \Omega\right)$. In order to accurately determine measurement during individual error, 5 measurement points, closest to lowest frequency were taken for sta- 
tistical comparison. The LOD for stainless steel working electrode was estimated at about $5.0 \% \mathrm{v} / \mathrm{v} \mathrm{CH} \mathrm{CH}_{3} \mathrm{OH}$ for small surface and $1.0 \% \mathrm{v} / \mathrm{v} \mathrm{CH}_{3} \mathrm{OH}$ for large surface. The LOD electrochemical cells with stainless steel covered with thin layer of $\mathrm{WO}_{3}$ working electrode was determined as low as $1.0 \% \mathrm{v} / \mathrm{v} \mathrm{CH}_{3} \mathrm{OH}$ for small device and as low as $0.5 \% \mathrm{v} / \mathrm{v}$ $\mathrm{CH}_{3} \mathrm{OH}$ for large device. It must be noted, that for large electrode covered with $\mathrm{WO}_{3}$ there were minor issues in detecting signals at higher concentrations, suggesting that there is a limit in concentration response. This suggests that it might be possible to increase LOD on the expense of range of concentrations. The data presented in Table1 was recorded at the frequency of $10^{-0.9} \mathrm{~Hz}$, while the graphs for estimate of LOD (Figures 9S-12S) along with Nyquist diagrams of LOD estimate measurements (Figures 13S-16S) are presented in supplementary information.

Table 1: Impedance of the large electrochemical cell with the stainless steel working electrode (S1), the small electrochemical cell with stainless steel working electrode (S2), the large electrochemical cell with the stainless steel electrode covered with $\mathrm{WO}_{3}$ working electrode (W1) and the small electrochemical cell with the stainless steel electrode covered with $\mathrm{WO}_{3}$ working electrode (W2) measured at percent by volume concentrations: $0.0,0.1,0.5,1.0,5.0,10,0$.

\begin{tabular}{|c|c|c|c|c|}
\hline & S1 & S2 & W1 & W2 \\
\hline \multicolumn{2}{|c|}{ Concentration (\%) } & \multicolumn{2}{|c|}{ Impedance $(\Omega)$} & \\
\hline 0.0 & $10^{4.95}$ & $10^{5.31}$ & $10^{4.60}$ & $10^{4.48}$ \\
\hline 0.1 & $10^{4.97}$ & $10^{5.32}$ & $10^{4.52}$ & $10^{4.45}$ \\
\hline 0.5 & $10^{4.98}$ & $10^{5.31}$ & $10^{4.43}$ & $10^{4.42}$ \\
\hline 1.0 & $\underline{10}^{4.74}$ & $10^{5.30}$ & $10^{4.36}$ & $\underline{10} \underline{4.39}$ \\
\hline 5.0 & $\overline{10}^{4.71}$ & $\underline{10} \underline{5.17}$ & $10^{4.28}$ & $\overline{10} 4.31$ \\
\hline 10.0 & $10^{4.42}$ & $10^{5.16}$ & $10^{4.27}$ & $10^{4.26}$ \\
\hline
\end{tabular}

\section{2. SEM Analysis}

The morphology of steel electrodes (Figure 4a) and steel electrodes coated with a layer of $\mathrm{WO}_{3}$ (Figure $4 \mathrm{~b}$ ) was observed by the scanning electron microscopy (SEM) technique at 100,000x magnification. On uncoated stainless steel surface shown in Figure 4a, it can be seen small crystals and slightly uneven surface, which is due to steel being prepared as 'hot-rolled' steel along with possible artefacts that could be made during production or handling of steel foil. This type of steel foil is known for its defects on surface compared to 'cold-rolled' steel and defects in form of crystals can be observed on photomicrography. As shown in Figure $4 \mathrm{~b}$, the stainless steel electrodes coated with a thin layer of $\mathrm{WO}_{3}$ are more porous than stainless steel electrodes (Figure 4a). This mesoporous surface is formed during sintering process of $\mathrm{WO}_{3}$ thin film preparation, and is due to fast heating and drying of thin film solgel $\mathrm{WO}_{3}$ precursor. This phenomena is well investigated and has been described in different literature. ${ }^{9}$ Due to porous structure of $\mathrm{WO}_{3}$ thin film, it has much higher roughness compared non-coated steel foil and because of this, yeast can more easily adhere onto surface. This data is in accordance with observations during preparation of devices, where $\mathrm{WO}_{3}$ coated steel foil had better adhesion of yeast compared to non-coated steel foil.

\section{3. Optical Microscopy}

The number of living cells of the yeast Saccharomyces cerevisiae on the surface of the electrodes was observed by optical microscopy. Methylene blue was used to check cell mortality, where dead cells remain blue stained and living cells reduce methylene blue and become colorless due to the reaction. With the addition of $0.9 \% \mathrm{NaCl}$ solution, yeast cells remained colorless (Figure $5 \mathrm{a}$ ). With the addition of $10 \% \mathrm{CH}_{3} \mathrm{OH}$ solution, the cells were blue stained (Figure 5b). By staining the cells with methylene blue dye it was additionally proven, that methanol causes the death of Saccharomyces cerevisiae yeast cells. It can be noticed that with a larger group of yeasts (top left in figure 5b),

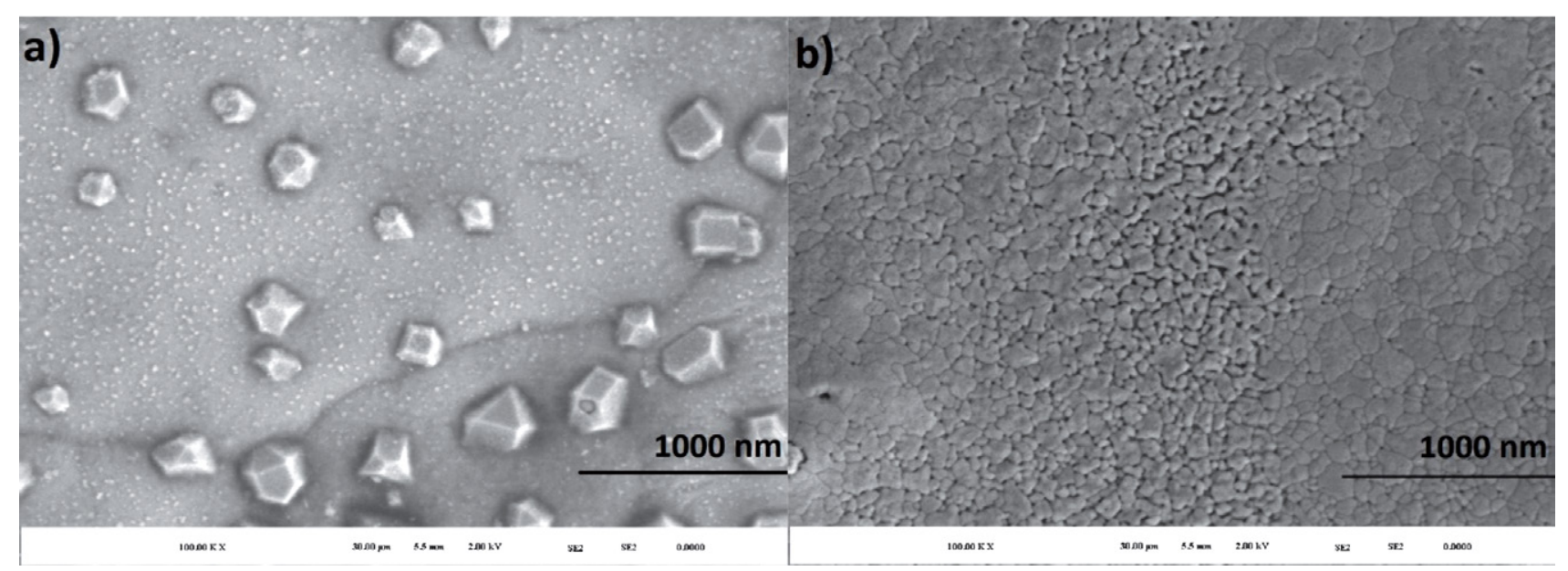

Figure 4: a) the SEM analysis (morphology) of stainless steel is presented. b) the SEM analysis (morphology) of stainless steel covered with a thin film of $\mathrm{WO}_{3}$ is presented. 


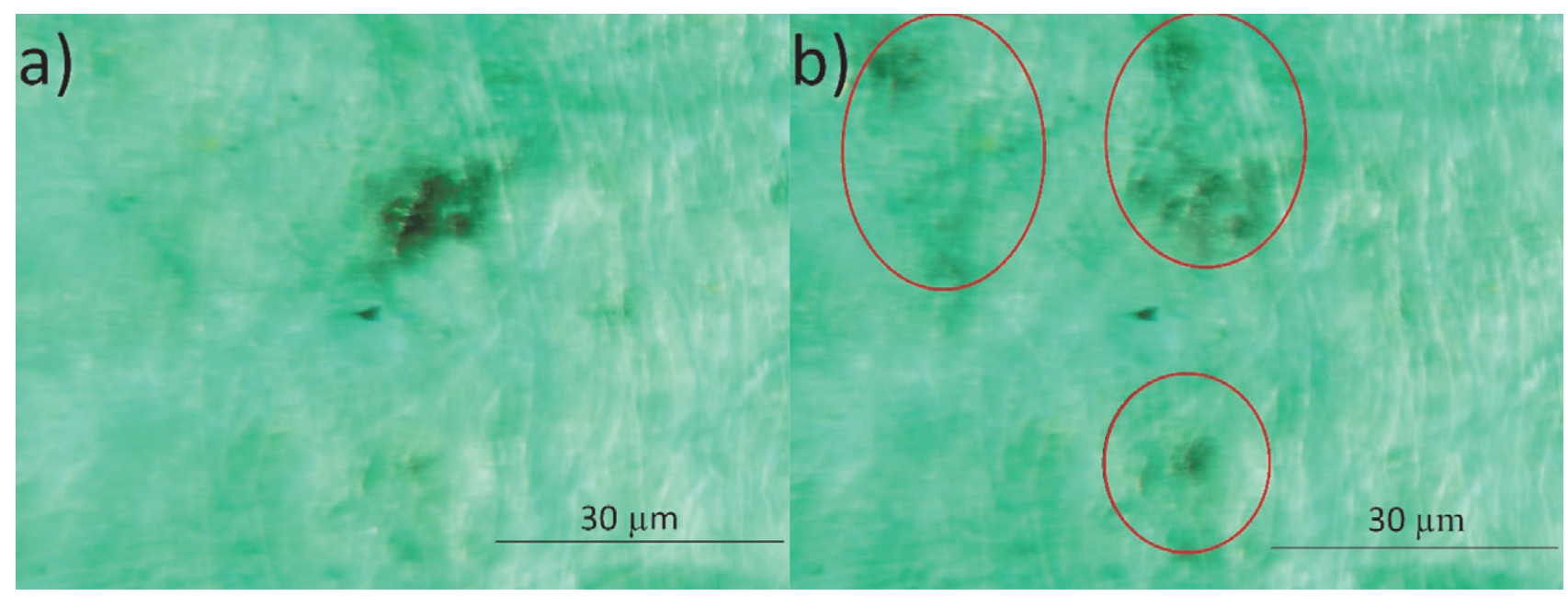

Figure 5: Microphotographs of the steel working electrode with adhered yeasts on covered with electrolyte carrier with methylene blue dye added along with $0.9 \% \mathrm{NaCl}$ (a) and along with $10 \% \mathrm{CH}_{3} \mathrm{OH}$ and $0.9 \% \mathrm{NaCl}(\mathrm{b})$. Both microphotographs are shown using $120 \mathrm{x}$ magnification

staining can be observed after the addition of $10 \% \mathrm{CH}_{3} \mathrm{OH}$ solution.

\section{Conclusions}

Electrochemical impedance spectroscopy (EIS) was used to obtain data on the yeast layer of Saccharomyces cerevisiae adhered on the electrode surface. The Nyquist diagrams of the investigated electrochemical cells show that the addition of $0.9 \% \mathrm{NaCl}$ solution with $10 \% \mathrm{CH}_{3} \mathrm{OH}$ decreased both the resistance and capacitance, suggesting that the electrode surface is released, and consequently it can be concluded, that methanol causes the death and desorption of yeast cells Saccharomyces cerevisiae. It was shown that all investigated electrochemical cells are effective in the detection of methanol in aqueous solutions. Large electrochemical cells where the active component is applied to a greater surface area $(5 \mathrm{~mm} \times 5 \mathrm{~mm})$ and stainless steel electrochemical cells coated with a layer of $\mathrm{WO}_{3}$ were found more effective. In the case of $0.050 \mathrm{~mm}$ thick electrochemical cells covered with a layer of $\mathrm{WO}_{3}$, several times lower capacitance and resistance was observed than in the case of stainless steel electrochemical cells. Moreover $\mathrm{WO}_{3}$ coated electrodes have lower conductivity compared to plain stainless steel electrodes and the yeast cells are better adhered onto the surface of the electrodes coated with $\mathrm{WO}_{3}$ due to greater porosity of surface. Using the method of staining cells with methylene blue it was shown that methanol causes the death of yeast cells Saccharomyces cerevisiae.

It was demonstrated that all investigated electrochemical biosensors are effective in detecting methanol in aqueous solutions and that they are applicable using less expensive portable potentiostat/galvanostat instruments. Therefore, this opens a new approach in the biosensors development where the key is to assemble an inexpensive and disposable electrochemical system, which can be used to detect harmful compounds. In the future, certain other toxins could be detected with yeast cells using our model of electrochemical biosensor assembly. Additionally, other biologically active components, such as enzymes, antibodies, or organ cells could be applied. Last but not least, low cost biosensors based on the presented approach, that would use simplified potentiostat/galvanostat, could be applied on large scale for environmental monitoring or even for medical diagnostics.

\section{Acknowledgments}

Financial support of the Slovenian Research Agency through programme (P2-0046, and P1-0403) as well as project (J1-2471) grants is gratefully acknowledged.

\section{References}

1. S. Singh, V. Kumar, D. S. Dhanjal, S. Datta, R. Prasad and J. Singh, Microbial Biotechnology: Basic Research and Applications 2020, 317-335. DOI:10.1007/978-981-15-2817-0_14

2. B. Caballero, L. C. Trugo and P. M. Finglas, Book Encyclopedia of food sciences and nutrition, Academic, 2003.

3. N. Bhalla, P. Jolly, N. Formisano and P. Estrela, Essays Biochem 2016, 60, 1-8. DOI:10.1042/EBC20150001

4. S. Kamel and T. A Khattab, Biosensors (Basel) 2020, 10, 67. DOI:10.3390/bios10060067

5. F. Karim and A. N. M. Fakhruddin, Reviews in Environmental Science and Bio/Technology 2012, 11, 261-274.

DOI:10.1007/s11157-012-9268-9

6. K. Dziąbowska, E. Czaczyk and D. Nidzworski: Biosensing Technologies for the Detection of Pathogens - A Prospective Way for Rapid Analysis, 2018.

DOI:10.5772/intechopen.72175 
7. T. Hoshikawa, M. Yamada, R. Kikuchi and K. Eguchi, Journal of Electroanalytical Chemistry 2005, 577, 339-348.

DOI:10.1016/j.jelechem.2004.11.040

8. R. Monošík, M. Stred'anský and E. Šturdík, J Clin Lab Anal 2012, 26, 22-34. DOI:10.1002/jcla.20500

9. M. Rozman, B. Žener, L. Matoh, R. F. Godec, A. Mourtzikou, E. Stathatos, U. Bren and M. Lukšič, Electrochimica Acta 2020, 330, 135329. DOI:10.1016/j.electacta.2019.135329

10. N. Cotolan, M. Rak, M. Bele, A. Cör, L. M. Muresan and I. Milošev, Surface and Coatings Technology 2016, 307, 790799. DOI:10.1016/j.surfcoat.2016.09.082

11. H. Martin-Yken, Biosensors (Basel) 2020, 10, 51. DOI:10.3390/bios10050051

12. G. G. Stewart, 2014, pp. 309-315. DOI:10.1016/B978-0-12-384730-0.00292-5

13. F. Farid, O. Sideeq, F. Khan and K. Niaz, 2019, pp. 501-508. DOI:10.1016/B978-0-12-812491-8.00066-7

14. S.-O. Suh, M. Blackwell, C. P. Kurtzman and M.-A. Lachance, Mycologia 2006, 98, 1006-1017.

DOI: $10.1080 / 15572536.2006 .11832629$

15. C. R. Landry, J. P. Townsend, D. L. Hartl and D. Cavalieri, Molecular Ecology 2006, 15, 575-591.
DOI:10.1111/j.1365-294X.2006.02778.x

16. J. Deacon, 2013, pp. 142-157. DOI:10.1002/9781118685068

17. F. Sherman, in: C. Guthrie and G. R. Fink (Eds.): Methods in Enzymology, Academic Press, 2002, pp. 3-41.

DOI:10.1016/S0076-6879(02)50954-X

18. N. Meddings, M. Heinrich, F. Overney, J.-S. Lee, V. Ruiz, E. Napolitano, S. Seitz, G. Hinds, R. Raccichini, M. Gaberscek and J. Park, Journal of Power Sources 2020, 480, 228742.

DOI:10.1016/j.jpowsour.2020.228742

19. N. Jaffrezic-Renault, in: K. Wandelt (Ed.): Encyclopedia of Interfacial Chemistry, Elsevier, Oxford, 2018, pp. 241-247. DOI:10.1016/B978-0-12-409547-2.13489-4

20. X. Fan, Z. Li, S. Wang, L. Liu, P. Liu, F. Chen and X. Zheng, Journal of the Brazilian Chemical Society 2019, 30, 1762-1768. DOI:10.21577/0103-5053.20190081

21. E. Randviir and C. Banks, Analytical methods 2013, 5, 10981115. DOI:10.1039/c3ay26476a

22. K. Kivirand, M. Min and T. Rinken: Environmental Biosensors, IntechOpen, 2019. DOI:0.5772/intechopen. 89334

23. K. Painting and B. Kirsop, World J Microbiol Biotechnol 1990, 6, 346-7. DOI:10.1007/BF01201311

\section{Povzetek}

Razvili smo elektrokemijsko celico, ki služi kot modelni biosenzor, ter kot aktivno biološko komponento vsebuje glive kvasovke Saccharomyces cerevisiae. Testirali smo različne postopke sestave elektrokemijskih celic, kjer smo uporabili nerjavno jeklo, površina kovinske elektrode pa je bila po potrebi modificirana s tanko plastjo volframovega trioksida $\left(\mathrm{WO}_{3}\right)$. Na delovno elektrodo smo adherirali kvasovke Saccharomyces cerevisiae. $\mathrm{Z}$ modelnim biosenzorjem smo nato spremljali odziv na $10 \%$ raztopino metanola pri različnih dimenzijah elektrod in modifikacijah površine. Za detekcijo smo uporabili metodo elektrokemijske impedančne spektroskopije (EIS), s katero smo merili frekvenčno odzivnost električnega toka in s tem pridobili podatke o adherirani plasti kvasovk na površinah elektrod, kot rezultat pa smo interpretirali Bodejeve in Nyquistove diagrame. Topografijo in sestavo elektrod smo dodatno preverjali s tehnikama vrstične elektronske mikroskopije in klasične optične mikroskopije. Predstavljeni biosenzor služi kot vzorčni primer za razvoj kompleksnejših biosenzorjev, ki kot aktivno plast uporabljajo žive celice.

Except when otherwise noted, articles in this journal are published under the terms and conditions of the Creative Commons Attribution 4.0 International License 